\title{
Rückspiegel
}

\section{Die Seite für Kinder}

\section{Brigitte Lutz-Westphal}

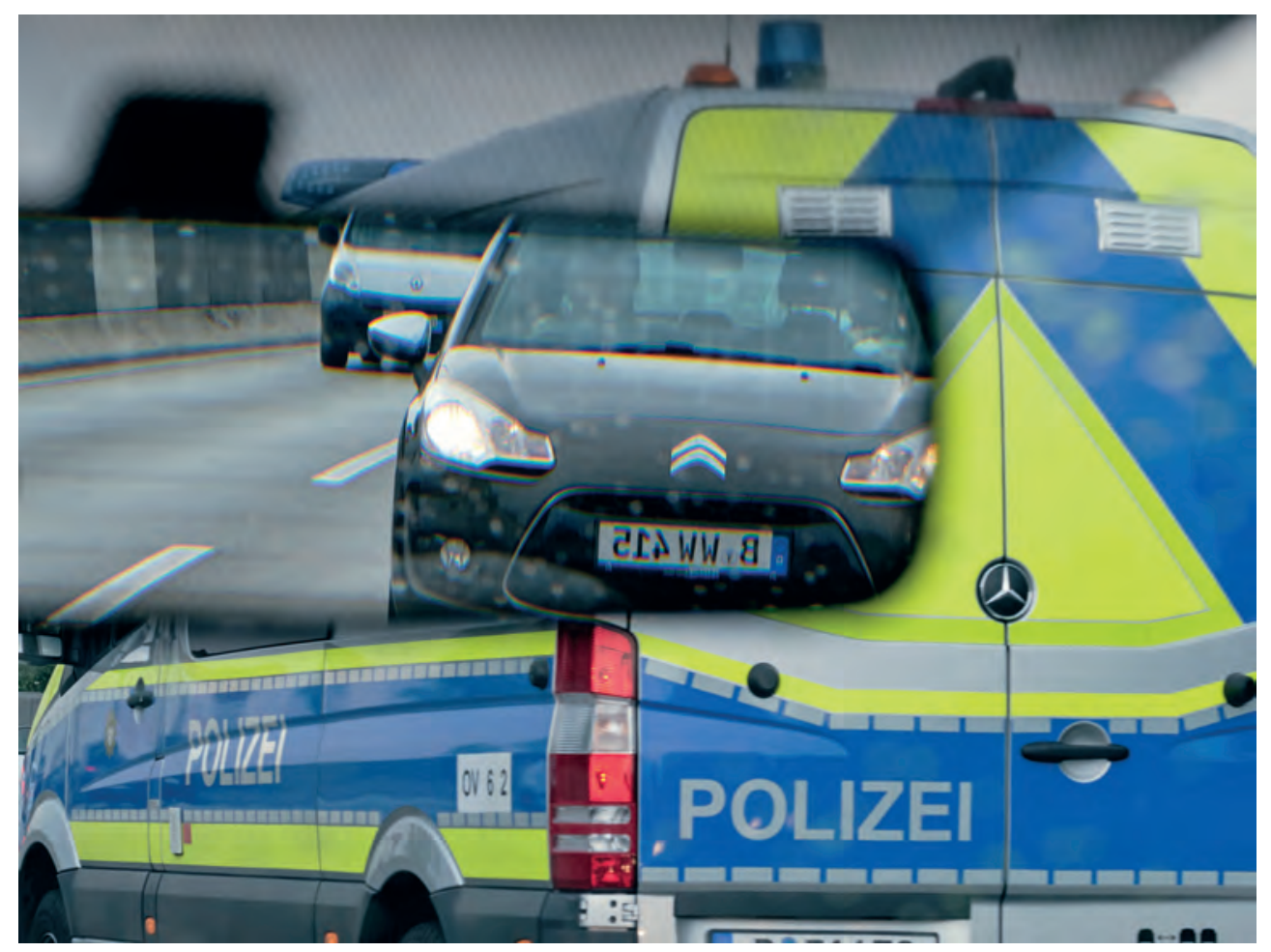

Wenn man im Auto sitzt und in den Rückspiegel schaut, ergibt sich ein spannendes Phänomen, sobald man ein anderes Auto hinter sich hat:

Man sieht die Person, die das andere Auto steuert, im Spiegelbild links sitzen, also dort, wo sie auch tatsächlich sitzt. Das Nummernschild aber sieht man seitenverkehrt.

Was ist hier los? 